
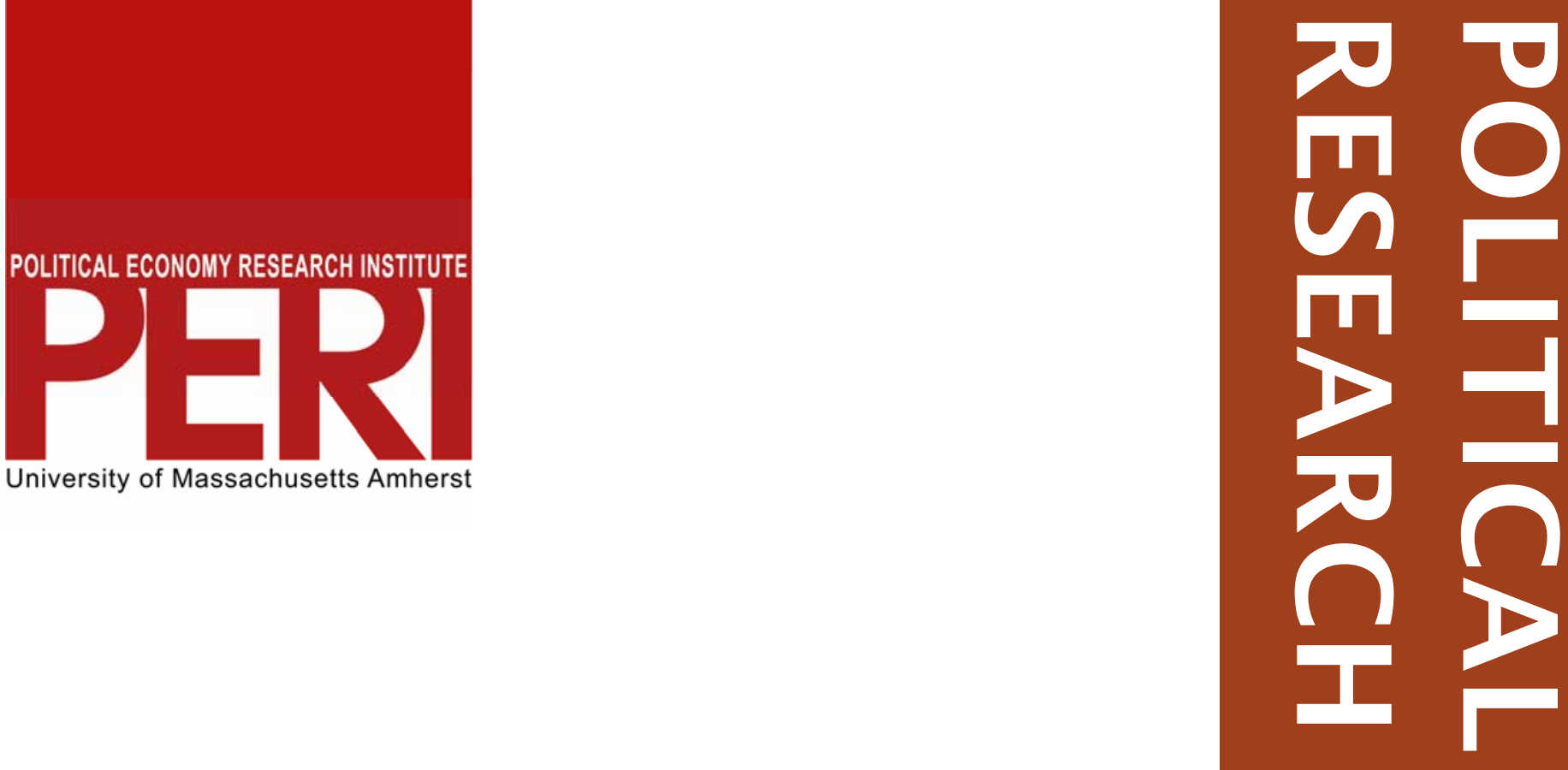

Can Progressive Taxation

Contribute to Economic Development?

Christian E. Weller \& Manita Rao

July 2008

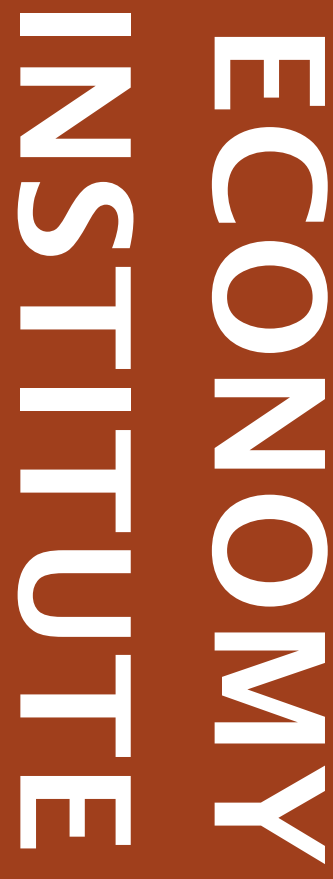

Gordon Hall

418 North Pleasant Street

Amherst, MA 01002

Phone: 413.545 .6355

Fax: 413.577 .0261

peri@econs.umass.edu www.peri.umass.edu 


\title{
Can Progressive Taxation Contribute to Economic Development?
}

\author{
Christian E. Weller \\ Department of Public Policy and Public Affairs \\ University of Massachusetts Boston \\ McCormack Building 03-420 \\ 100 Morrissey Boulevard \\ Boston, MA 02125 \\ and \\ Manita Rao \\ Ph.D. candidate \\ Department of Public Policy and Public Affaire \\ University of Massachussets Boston
}

\begin{abstract}
Financial instability has increased for many economies in the face of greater capital mobility. Eliminating capital flows, especially portfolio investment flows, may reduce volatility, but it could also result in domestic capital constraints. To overcome this dilemma, policymakers may consider alternatives, such as progressive income taxation, that could raise domestic funds. In this paper, we combine several macro economic data sources to test the link between progressive taxation and economic stability, economic growth, inequality and fiscal policy. Based on data from 1981 to 2002, we find that progressive taxation provides policymakers with the ability to conduct countercyclical fiscal policies, which in turn contributes significantly to economic stability. In turn, we find no evidence that progressive taxation adversely affects economic stability by reducing growth. We find, though, that the possibility to raise the progressiveness is constrained by capital mobility and by the level of government spending. Finally, policymakers, who may consider consumption taxes, such as the value added taxes (VAT), when tax enforcement is ineffective, would see no additional gains in terms of economic stability from the implementation of a VAT in combination with progressive income taxation.
\end{abstract}

Keywords: Progressive personal income taxation; value added taxes; long-term growth; economic stability; income inequality; government revenue; fiscal balances. 


\section{Introduction}

Policymakers in industrializing economies face a dilemma. Many countries have opened their borders to international capital inflows to reduce domestic financial constraints, but capital account liberalization often sparks a wave of speculative financing, resulting in economic volatility with serious ramifications especially for a country's poor.

One option to resolve this dilemma may be to generate more domestic saving, specifically through more progressive personal income taxation. In countries with fairly unequal income distributions, more progressive taxation could translate into the generation of more stable, long-term financial resources and a greater ability of policymakers to engage in countercyclical fiscal policies. Both could help stabilize financial development and make economic growth more durable and boost domestic fixed capital formation. Progressive taxation can also indirectly affect stability by impacting trends that are associated with less volatility, such as more equal income distribution.

On the other hand, some researchers have argued that progressive taxation could stymie economic growth as it could reduce the incentives for investment and human capital formation. Also, greater revenue generation could crowd out domestic capital available for productive investment, thereby hampering growth.

Importantly, the implementation of progressive personal income taxation may be constrained by outside factors, chief among them the level of government spending. Moreover, tax policy is set in the context of increased global financial integration. Capital may flow to countries that offer the best risk-return profile, which countries may want to influence by lowering corporate taxes. Thus, corporate tax competition and capital account liberalization may constrain policymakers' ability to design their tax systems. An additional constraint may be effective tax collection. Industrializing countries hence may consider implementing a consumption tax, such as the value added tax (VAT) to improve tax compliance.

Our research is a first attempt to evaluate progressive personal income taxation as a tool to stabilize output in industrializing economies. We thus build on the existing literature in several ways. First, we provide a comprehensive, empirical look at the link between progressive personal income taxation and a range of economic outcomes, to see if such tax design can contribute to economic stability in open industrializing economies. Second, we study the potential constraints on establishing progressive personal income taxation in industrializing economies. Third, we consider VATs as an alternative revenue source and its connection to economic stability.

\section{Progressive Income Taxation and Economic Stability}

Policymakers in industrializing economies typically focus on capital account liberalization to raise capital, often in the form of short-term portfolio capital inflows. Greater portfolio capital inflows can reduce capital constraints and foster financial market developments (Durham 2003; Levine 1997; Litan et al. 2001). 
This may, however, come at the price of greater volatility (Arestis and Demetriades 1999; Grabel 1998; Demirgüç-Kunt and Detragiache, 1999; Kaminsky and Reinhart, 1999; Weller 2001). Greater capital inflows may heighten expectations and thus help to create an, ultimately unsustainable, asset price boom (Eichengreen, Rosen, and Wyplosz, 1998; Grabel 1998; Kaminsky and Reinhart, 1999; Weller, 2001). Also, weak domestic institutions can contribute to greater instability in the face of increased capital mobility. To some degree, high-quality institutions, such as effective supervision or macro economic stability, can mitigate the rising chance of financial crises, but they cannot eliminate them (Alba et al. 1999; Arestis and Demetriades 1999; Demetriades and Fattouh 1999).

Policymakers could focus on increasing national saving, e.g. through more progressive taxation, to replace external capital flows. Other taxes, such as tariffs and corporate taxes, have typically played as large or even larger roles than personal income taxes in industrializing economies. But, increased trade liberalization has left many countries looking for new sources of revenue. For instance, the share of taxes from trade declined in Latin America from 26.8\% between 1975 and 1980 to 13.3\% between 1996 and 2002 (Bird and Zolt, 2005).

Progressive income taxation may be especially appealing in industrializing economies that often have highly unequal income distribution, which seems to have increased in many countries. There was an unambiguous rise in inequality in Latin America in the 1980s and 1990s (Lustig and Deutsch, 1998; IADB, 1999; UNCTAD, 1997; ECLAC, 1997). And other areas also saw inequality rise in the 1980s and 1990s (Faux and Mishel, 2000; Ravallion and Chen, 1997). Deininger and Squire (1996) found rising inequality in East Asia, Eastern Europe, and Central Asia since 1981, and growing polarization in South Asia. While in China the poverty rate has fallen, there has been a rapid rise in inequality from 1985 to 1995 (WB, 2001b).

The potential for additional revenue can be large. While personal income taxes constituted $25.0 \%$ of all taxes in industrialized economies, they amounted only to $9.1 \%$ in industrializing economies from 1990 to 2001 (Bird and Zolt, 2005). Many tax systems in industrializing countries are substantially less progressive than those in industrialized countries (Schmitt, 2003), implying that greater progressiveness could result in more revenue since a greater share of revenue would be borne by higher-income earners. Picketty and Qian (2006), for example, estimate that rising inequality in China could result in revenue generation from the income tax equal to $4.0 \%$ in 2010 , as compared to $1.0 \%$ in 2000 , and $0.1 \%$ in 1990 .

In the same vein, more progressive taxation could improve the automatic stabilizer function of a country's fiscal system. As output declines and income with it, after-tax income declines are disproportionately smaller than before-tax income drops, due to the progressiveness of the personal income tax. Auerbach and Feenberg (2000), for instance, argue that progressive taxation can serve as an automatic stabilizer and that this effect could be as large as traditional demand mechanisms. Also, Swanepol and Schoeman (2002) find that South Africa's taxation system has played a role as automatic stabilizer as tax revenue and the output gap are highly correlated. Hence, more progressive taxes could directly help stabilize output fluctuations.

More tax progressiveness could impact volatility over time by reducing income inequality. Progressive income taxation tends to affect income inequality by equalizing the after- 
tax income distribution. Hassan and Bogetic (1999), for instance, find that progressive Bulgarian income taxes helped to reduce inequality. This finding is not universal, as Engel et al. (1998), for example, conclude that the Chile's tax system had little effect on after-tax inequality.

If more progressive taxation, however, is associated with a more equal income distribution, it could contribute to less output volatility. Specifically, a more equitable income distribution could help to stabilize domestic demand and thus reduce financial and economic volatility. The same indirect link seems to exist between civil liberties and political freedom, whereby more civil liberties and political freedoms translate into a more equitable income distribution and thus more stable demand and output growth (Weller and Singleton, 2004).

A second more long-term link between progressive taxation and stability may exist through the connection to economic growth, although the direction of the link is a priori unclear. Progressive taxation, for instance, could in theory adversely affect skill development, although this argument has little empirical support. Specifically, progressive taxation may discourage unskilled workers from developing their skills (Caucutt et al., 2006; Bovenberg and van Ewijk, 1997). The empirical evidence, though, does not lend support to this theoretical link. Li and Sartre (2001, 2004) show that once the model allows heterogeneity across households, tax progressiveness does not adversely impact growth. And in a survey of the existing literature, Roed and Storm (2002) argue that progressive taxes do not necessarily have to lead to slower growth, depending on the labor elasticity of low wage workers, on wage bargaining strength, and on individuals' preferences. And, a more progressive tax system allows for more labor income risk sharing among workers. Consequently, there may be efficiency gains from introducing progressive income taxation if wage income is not insurable (Nishiyama and Smetters, 2005). The result could produce enhanced skill formation and faster long-run economic growth.

Progressive income taxation could impact physical capital formation. A more progressive tax system may reduce the amount of private saving available to finance domestic investment. This could translate into higher cost of capital and thus impede physical capital formation. On the other hand, international capital flows may compensate for the loss of domestic saving and the scale of the effect of capital costs on investment has traditionally been much smaller than other determinants, such as sales growth. Importantly then, if progressive taxation helps to stabilize, if not accelerate, domestic sales growth, this indirect positive effect of progressive taxation on investment will likely offset the negative impact of higher cost of capital. ${ }^{1}$ This may be further supported by the argument that a more progressive tax system could increase consumption. Barsky et al. (1986), for example, argue that income tax cuts can lead to positive effects on consumption, boosting economic growth. In the end, progressive income taxation may have either no effect or even a positive impact on physical capital formation.

Furthermore, progressive taxation can improve the prospects for growth if it reduces economic volatility. For instance, Ramey and Ramey (1995) find a strong negative link between volatility and growth, such that countries with higher volatility experience slower growth.

Policymakers may be constrained in designing tax policy. One obvious constraint is that countries need to finance a given level of expenditures, at least in the short run (Mello, 2007).

\footnotetext{
${ }^{1}$ See Leibfritz, Thornton, and Bibbee (1997) for a detailed survey of the theoretical and empirical literature.
} 
An additional constraint may be corporate tax competition. Open economies may cut corporate taxes to attract mobile capital (Oates 1972, Zodrow and Mieszkowski 1986, Wilson 1986; DeMello, 2007). The evidence, though, on tax competition is limited since governments may use other means to attract mobile capital (Benassy-Quere, Gobalraja, and Trannoy, 2007; Davies and Ellis, 2007) and since the implementation of tax competition is influenced by multiple factors including demand elasticity of taxed goods, cost inelasticity caused by smuggled goods across municipal borders, and co-occupation of federal and state taxes (Devereux, Lockwood, and Redoano 2006; DeMello 2007). If countries, however, systematically engage in tax competition, governments will have to compensate for the reduced revenue by generating additional revenues from less mobile labor (Leibfritz, Thornton, and Bibbee, 1997). This could result in more progressive income taxation to begin with, which could limit the ability of policymakers to further increase the progressiveness of personal income taxation.

A second constraint may be the effectiveness of the tax collection system (Bird and Zolt, 2005). Because tax collection is often ineffective and greater enforcement introduces a regressive bias (Galmarini, 1997; Scotchmer, 1992), many industrializing economies consider the implementation of a VAT as an alternative revenue source. To compensate for the regressiveness of a VAT, its implementation is often accompanies by progressive elements, such as an exclusion of basic consumption items or the addition of a luxury item surcharge (Balassa, 1989).

The evidence on the regressiveness of the VAT is mixed. Thierfelder et al. (2005) found the VAT in South Africa to be mildly regressive. Also, Engel et al. (1998) argue that substituting the progressive income tax system in Chile with a VAT would impact the after-tax income distribution only slightly. And, some researchers have even argued that a VAT can be progressive. For instance, Jenkins et al. (2006) argue that the application of the VAT in the Dominican Republic led to progressive effective taxation because many of the consumption items that lower-income families spend large shares of their income on are not taxed. Also, Decoster (2005) finds the VAT in Russia to be progressive. And, Munoz and Sang-Wook Cho (2003) argue that the incidence of the VAT in Ethiopia was progressive. A VAT may hence be a suitable replacement for ineffectively applied progressive income taxes.

\section{Univariate analysis}

We proceed in four steps in the univariate analysis. We first consider the evidence of a direct link between progressive taxes and economic stability, substitution of capital inflows, and countercyclical fiscal policy. Next, we analyze the possible indirect links between progressive taxation and income inequality, economic growth, and investment. Furthermore, we consider the link between external constraints - corporate tax rates, capital account openness, government spending, and VAT levels - and the progressiveness of personal income taxes. And finally, we consider if progressive personal income taxation performs better with respect to economic stability than a VAT does.

Macroeconomic data are taken from the IMF's International Financial Statistics. These include data on GDP, taxes, fiscal balances, investment, and portfolio flows. In particular, we

define three fiscal measures, including taxes to GDP, fiscal balances to GDP, and an indicator for 
countercyclical fiscal policy. This indicator takes on the value of "1" if the fiscal balance to GDP decreases when growth is at least one standard deviation below the average growth rate for each country or if the budget balance improves when growth is above this threshold. Otherwise, this indicator takes on the value of " 0 ". Also, we use the 5-year average real GDP growth rate as growth measure and the 5-year standard deviation of growth and the 5-year standard deviation of growth relative to the average growth rate during the same five years as volatility measures.

Income inequality data are from the UNU/WIDER World Income Inequality Database. Progressive taxation should result in more income equality, which is measured here by the income share of the bottom $20 \%$. Where observations are missing, the share of income for the bottom 20\% are calculated based on the methodology used by Dollar and Kraay (2001a).

Further, data on capital account openness are from the IMF's Exchange Rate Arrangements and Restrictions Yearbook. We define countries as open if the number of capital flow types that have restrictions is smaller than the number without restrictions after 1994.

The tax data are collected from a number of sources. ${ }^{2}$ We use the top marginal tax rate, the average tax rate and the median tax rate to measure the progressiveness of personal income taxes - all from the American Enterprise Institute's International Tax Database. ${ }^{3}$ We also consider the top marginal tax rate from the Fraser Institute's Economic Freedom Database. In each case, higher values should approximate a more progressive personal income tax system. ${ }^{4}$

The data show a decline in tax progressiveness from 1981 to 2002 (Table 1). The top marginal tax rate in 1981 averaged to $52.7 \%$ according to the data from the Fraser Institute (2005) and to 58.4\% according to data from AEI (2006). By 2002, the average top marginal tax rate had fallen to $31.3 \%$ and $33.8 \%$, respectively. Over the same time period, the average tax rate declined from $32.8 \%$ to $24.3 \%$ and the median tax rate fell slightly less from $31.7 \%$ to $24.4 \%$.

The declines in the average and median tax rates are proportionately much smaller than the declines in the top marginal tax rates. While the top tax rates declined by $40.6 \%$ in the Fraser Institute data and by $40.4 \%$ in the AEI data, the average tax rate declined by $26.1 \%$ (Table 1 ). Also, the median tax rate declined by $22.8 \%$, less than the average tax rate. This suggests that taxation became less progressive over time.

This decline in tax progressiveness occurred even though corporate tax rates dropped, too. Average corporate tax rates fell by $28.9 \%$ and median rates by $22.8 \%$ (Table 1 ). These decreases, though, were larger than those for personal income tax rates.

Offsetting these declines were increases in the VAT. On average, VAT rates increased by close to $200 \%$, from $1.9 \%$ in 1981 to $5.6 \%$ in 2002 (Table 1).

\footnotetext{
${ }^{2}$ We use all available observations in each case. The results, though, would remain the same if we used only complete observations. Details are available from the authors.

${ }^{3}$ We are grateful to Kevin Hassett for sharing the data set with us. A full description of the data set and the initial analysis of the data can be found in Hassett and Mathur (2006).

${ }^{4}$ The data do not allow us to control for effective tax rates.
} 
Table 1

Summary Tax Data for Industrializing Economies, 1981 to 2002

\begin{tabular}{|c|c|c|c|c|c|c|c|}
\hline & $\begin{array}{c}\text { Top } \\
\text { marginal } \\
\text { personal } \\
\text { income tax } \\
\text { rate (Fraser } \\
\text { Institute) }\end{array}$ & $\begin{array}{c}\text { Top } \\
\text { marginal } \\
\text { personal } \\
\text { income tax } \\
\text { rate (AEI) }\end{array}$ & $\begin{array}{c}\text { Average } \\
\text { personal } \\
\text { income tax } \\
\text { rate }\end{array}$ & $\begin{array}{c}\text { Median } \\
\text { personal } \\
\text { income tax } \\
\text { rate }\end{array}$ & $\begin{array}{l}\text { Value added } \\
\text { tax }\end{array}$ & $\begin{array}{c}\text { Average } \\
\text { corporate } \\
\text { tax rate }\end{array}$ & $\begin{array}{c}\text { Median } \\
\text { corporate } \\
\text { tax rate }\end{array}$ \\
\hline 1981 & 52.7 & 56.5 & 32.8 & 31.7 & 13.8 & 39.4 & 39.4 \\
\hline 1982 & 52.3 & 55.8 & 32.7 & 31.9 & 14.1 & 39.7 & 39.6 \\
\hline 1983 & 52.0 & 54.9 & 32.9 & 32.4 & 14.0 & 39.3 & 39.4 \\
\hline 1984 & 51.6 & 54.4 & 32.3 & 31.7 & 13.3 & 38.9 & 39.0 \\
\hline 1985 & 50.9 & 52.4 & 31.1 & 30.5 & 13.4 & 38.4 & 38.5 \\
\hline 1986 & 49.2 & 50.2 & 30.0 & 29.5 & 13.5 & 37.5 & 37.5 \\
\hline 1987 & 47.5 & 48.7 & 29.6 & 29.1 & 13.6 & 36.9 & 37.0 \\
\hline 1988 & 45.8 & 46.4 & 28.1 & 27.7 & 13.5 & 36.0 & 36.1 \\
\hline 1989 & 44.1 & 45.5 & 30.0 & 29.5 & 13.6 & 36.7 & 36.7 \\
\hline 1990 & 42.9 & 44.7 & 28.9 & 28.4 & 13.5 & 36.4 & 36.4 \\
\hline 1991 & 41.3 & 41.8 & 27.0 & 26.7 & 13.5 & 35.1 & 35.1 \\
\hline 1992 & 39.5 & 39.5 & 25.9 & 25.7 & 13.7 & 34.1 & 34.0 \\
\hline 1993 & 37.7 & 38.4 & 25.1 & 24.9 & 14.1 & 32.9 & 33.0 \\
\hline 1994 & 35.9 & 37.3 & 25.1 & 25.2 & 13.2 & 32.0 & 32.0 \\
\hline 1995 & 35.0 & 37.4 & 25.0 & 24.9 & 14.1 & 31.4 & 31.4 \\
\hline 1996 & 34.4 & 36.2 & 24.5 & 24.5 & 13.8 & 30.9 & 30.9 \\
\hline 1997 & 33.9 & 35.0 & 23.9 & 23.9 & 14.3 & 30.5 & 30.5 \\
\hline 1998 & 33.4 & 34.7 & 24.1 & 24.0 & 14.1 & 30.5 & 30.4 \\
\hline 1999 & 32.9 & 34.9 & 24.0 & 23.8 & 14.1 & 30.1 & 30.0 \\
\hline 2000 & 32.5 & 34.8 & 23.7 & 23.5 & 14.2 & 29.7 & 29.6 \\
\hline 2001 & 31.5 & 34.0 & 23.7 & 23.6 & 14.5 & 29.0 & 28.9 \\
\hline 2002 & 31.3 & 33.7 & 24.3 & 24.4 & 14.7 & 28.2 & 28.0 \\
\hline $\begin{array}{l}1981 \text { to } \\
2002 \\
\text { (percent } \\
\text { change) }\end{array}$ & -40.6 & -40.4 & -26.1 & -22.8 & 6.5 & -28.4 & -28.9 \\
\hline
\end{tabular}

Notes: All figures are unweighted averages. Missing data are interpolated. Only data for industrializing economies are included. Calculations are based on unbalanced panel. Changes are calculated based on averages across all available countries in a given year. Calculations based on Fraser Institute (2005) and AEI (2006).

\section{III.1 Tax Progressiveness and Economic Stability}

We divide the data into two groups. The relevant variables are summarized for countries that have tax rates above the median and for those that have tax rates below the median for all industrializing economies. We then compare the value of our variables of interest in countries with more progressive personal income taxes to those of less progressive tax systems.

There is no robust link between tax progressiveness and economic stability. The standard deviation of growth is higher with less progressive taxation in two out of four cases (Table 2). 
The link between volatility and tax progressiveness depends on the measure of stability and on the variable to capture tax progressiveness. Also, there is no difference in the level of capital inflows at varying levels of progressiveness. When we consider only instances, when portfolio investment flows are present, which are the cases, to which the primary theoretical arguments about liberalization and volatility pertain, the results do not change materially (Table 3).

Progressive income taxation seems to permit countries to engage in countercyclical fiscal policy. Revenues are larger with more progressive income taxation, which means that countries can engage in more expansionary fiscal policy, when needed. Progressiveness is associated with a higher chance of engaging in countercyclical fiscal policy. In three out of four cases, the probability of engaging in countercyclical fiscal policy is approximately ten percent higher in countries with more progressive taxation than in countries with less progressive one. These countries may also have a desire to expand social expenditures due to more egalitarian preferences as witnessed by the fact that progressive taxation is linked to systematically less income inequality. More countercyclical policies and more egalitarian preferences may help explain why deficits are also greater with progressive taxation (Tables 2 and 3).

The conclusions on growth and investment tend to depend on the measure for tax progressiveness. Growth is faster in countries with more progressive taxation in only one out of four cases, although the average difference is close to zero and statistically insignificant (Table 2). When we consider only cases, when portfolio inflows are present, we find two out of four cases, when growth is faster with more tax progressiveness (Table 3). Investment is higher in two out of four cases, although the difference is statistically insignificant in half of the cases (Tables 2 and 3). Progressive taxation is not systematically linked to growth and investment. 
Table 2

Economic Outcomes under Different Personal Income Tax Regimes

\begin{tabular}{|c|c|c|c|c|c|c|c|c|c|c|c|}
\hline & \multirow{2}{*}{$\begin{array}{l}\text { Exp. sign } \\
\text { of } \\
\text { difference } \\
\end{array}$} & \multirow[t]{2}{*}{$\begin{array}{c}\text { Pct. } \\
\text { correct }\end{array}$} & \multirow[t]{2}{*}{$\begin{array}{l}\text { Avg. } \\
\text { diff. }\end{array}$} & \multicolumn{2}{|c|}{$\begin{array}{l}\text { Top marginal tax rate } \\
\text { (Fraser) }\end{array}$} & \multicolumn{2}{|c|}{$\begin{array}{l}\text { Top marginal tax rate } \\
\text { (AEI) }\end{array}$} & \multicolumn{2}{|c|}{ Avg. tax rate } & \multicolumn{2}{|c|}{ Med. Tax rate } \\
\hline & & & & $\begin{array}{l}\text { Below } \\
\text { median }\end{array}$ & $\begin{array}{l}\text { Above } \\
\text { median }\end{array}$ & $\begin{array}{l}\text { Below } \\
\text { median }\end{array}$ & $\begin{array}{l}\text { Above } \\
\text { median }\end{array}$ & $\begin{array}{l}\text { Below } \\
\text { median }\end{array}$ & $\begin{array}{l}\text { Above } \\
\text { median }\end{array}$ & $\begin{array}{l}\text { Below } \\
\text { median }\end{array}$ & $\begin{array}{l}\text { Above } \\
\text { median }\end{array}$ \\
\hline \multicolumn{12}{|l|}{$\begin{array}{l}\text { Government } \\
\text { finances }\end{array}$} \\
\hline Taxes/GDP & “+” & $\begin{array}{l}100 \\
(75)\end{array}$ & 3 & 21.9 & $\begin{array}{c}22.2 \\
(0.493)\end{array}$ & 20.6 & $\begin{array}{l}23.8^{* * *} \\
(3.778)\end{array}$ & 20.9 & $\begin{array}{l}24.3 * * * \\
(4.656)\end{array}$ & 20.4 & $\begin{array}{c}24.9 * * * \\
(6.069)\end{array}$ \\
\hline Govt. balance/GDP & “+” & $\begin{array}{c}0 \\
(0)\end{array}$ & -2 & -2.1 & $\begin{array}{l}-4.0 * * * \\
(-6.382)\end{array}$ & -1.8 & $\begin{array}{l}-3.4^{* * *} \\
(-5.308)\end{array}$ & -1.9 & $\begin{array}{l}-3.6^{* * *} \\
(2.820)\end{array}$ & -1.7 & $\begin{array}{l}-3.6^{* * *} \\
(-4.696)\end{array}$ \\
\hline $\begin{array}{l}\text { Prob. of } \\
\text { countercyclicality } \\
\text { Stability }\end{array}$ & “+” & $\begin{array}{l}75 \\
(0)\end{array}$ & 2 & 31.8 & $\begin{array}{c}31.2 \\
(0.281)\end{array}$ & 29.2 & $\begin{array}{c}32.3 \\
(-0.827)\end{array}$ & 29.5 & $\begin{array}{c}31.6 \\
(-0.809)\end{array}$ & 29.0 & $\begin{array}{c}31.6 \\
(-0.912)\end{array}$ \\
\hline Growth volatility & “_“ & $\begin{array}{l}50 \\
(25)\end{array}$ & 1 & 6.1 & $\begin{array}{c}5.2 \\
(-0.658)\end{array}$ & 7.1 & $\begin{array}{c}4.1^{*} \\
(-1.637)\end{array}$ & 3.4 & $\begin{array}{l}6.2 * * * \\
(2.820)\end{array}$ & 3.4 & $\begin{array}{c}7.6 * * \\
(2.203)\end{array}$ \\
\hline $\begin{array}{l}\text { Rel. growth } \\
\text { volatility }\end{array}$ & “_““ & $\begin{array}{l}25 \\
(0)\end{array}$ & 47 & 129.1 & $\begin{array}{c}60.4 \\
(0.965)\end{array}$ & 47.4 & $\begin{array}{c}114.7 \\
(1.318)\end{array}$ & 59.7 & $\begin{array}{c}139.1 \\
(1.433)\end{array}$ & 38.1 & $\begin{array}{l}148.6^{*} \\
(1.850)\end{array}$ \\
\hline PI flows/GDP & “_“ & $\begin{array}{c}25 \\
(25)\end{array}$ & 0 & 0.9 & $\begin{array}{c}0.4^{* *} \\
(-2.480)\end{array}$ & 0.7 & $\begin{array}{c}0.7 \\
(-0.464)\end{array}$ & 0.7 & $\begin{array}{c}0.7 \\
(0.149)\end{array}$ & 0.7 & $\begin{array}{c}0.8 \\
(0.389)\end{array}$ \\
\hline $\begin{array}{l}\text { Inequality } \\
\text { Share of bottom } 20\end{array}$ & “+” & $\begin{array}{l}100 \\
(100)\end{array}$ & 1 & 4.8 & $\begin{array}{l}5.1 * * * \\
(2.573)\end{array}$ & 4.8 & $\begin{array}{l}5.5^{* * *} \\
(2.971)\end{array}$ & 4.7 & $\begin{array}{l}5.7 * * * \\
(6.213)\end{array}$ & 4.5 & $\begin{array}{l}5.7 * * * \\
(7.576)\end{array}$ \\
\hline $\begin{array}{l}\text { 5-year average } \\
\text { growth }\end{array}$ & “+” & $\begin{array}{c}0 \\
(0)\end{array}$ & -1 & 5.0 & $\begin{array}{c}4.2 \\
(-0.300)\end{array}$ & 4.6 & $\begin{array}{c}3.7 * * * \\
(-2.961)\end{array}$ & 4.4 & $\begin{array}{c}3.6^{* * *} \\
(-3.068)\end{array}$ & 4.3 & $\begin{array}{c}3.7 \\
(-1.987)\end{array}$ \\
\hline $\begin{array}{l}\text { Investment/ } \\
\text { GDP }\end{array}$ & “+” & $\begin{array}{l}50 \\
(25)\end{array}$ & 0 & 22.0 & $\begin{array}{c}21.4 \\
(-0.922)\end{array}$ & 21.5 & $\begin{array}{l}22.4^{* *} \\
(2.114)\end{array}$ & 22.4 & $\begin{array}{c}21.8 \\
(-1.435)\end{array}$ & 21.8 & $\begin{array}{c}22.0 \\
(0.319)\end{array}$ \\
\hline
\end{tabular}

Notes: Differences are the average for more progressive tax systems minus the respective average of less progressive tax systems. All figures are in percent. See the text for variable definitions, data sources, and explanation of expected sign. For the percent of correct expectations, instances of no differences are counted as incorrect expectations. PI flows stands for portfolio investment. Figures in parentheses for comparisons are t-statistics and for "pct. Correct” refer to the percent of differences that have the correct expected sign and are statistically significant. * indicates significance at the $10 \%$-level, $* *$ indicates significance at the $5 \%$ level and *** indicates significance at the $1 \%$-level. 
Table 3

Economic Outcomes under Different Personal Income Tax Regimes When Portfolio Investment Flows are Present

\begin{tabular}{|c|c|c|c|c|c|c|c|c|c|c|c|}
\hline & \multirow{2}{*}{$\begin{array}{l}\text { Exp. Sign } \\
\text { of } \\
\text { difference } \\
\end{array}$} & \multirow[t]{2}{*}{$\begin{array}{l}\text { Pct. } \\
\text { correct }\end{array}$} & \multirow[t]{2}{*}{$\begin{array}{l}\text { Avg. } \\
\text { diff. }\end{array}$} & \multicolumn{2}{|c|}{$\begin{array}{l}\text { Top marginal tax rate } \\
\text { (Fraser) }\end{array}$} & \multicolumn{2}{|c|}{$\begin{array}{l}\text { Top marginal tax rate } \\
\text { (AEI) }\end{array}$} & \multicolumn{2}{|c|}{ Avg. tax rate } & \multicolumn{2}{|c|}{ Med. Tax rate } \\
\hline & & & & $\begin{array}{l}\text { Below } \\
\text { median }\end{array}$ & $\begin{array}{l}\text { Above } \\
\text { median }\end{array}$ & $\begin{array}{l}\text { Below } \\
\text { median }\end{array}$ & $\begin{array}{l}\text { Above } \\
\text { median }\end{array}$ & $\begin{array}{l}\text { Below } \\
\text { median }\end{array}$ & $\begin{array}{l}\text { Above } \\
\text { median }\end{array}$ & $\begin{array}{l}\text { Below } \\
\text { median }\end{array}$ & $\begin{array}{l}\text { Above } \\
\text { median }\end{array}$ \\
\hline $\begin{array}{l}\text { Government } \\
\text { finances }\end{array}$ & & & & & & & & & & & \\
\hline Taxes/GDP & $“+”$ & $\begin{array}{l}100 \\
(75)\end{array}$ & 3 & 22.7 & $\begin{array}{c}23.8 \\
(1.364)\end{array}$ & 21.0 & $\begin{array}{c}24.7^{* * *} \\
(3.289)\end{array}$ & 21.4 & $\begin{array}{l}25.2 * * * \\
(4.630)\end{array}$ & 21.3 & $\begin{array}{r}25.6^{* * *} \\
(5.009)\end{array}$ \\
\hline Govt. balance/GDP & “+” & $\begin{array}{c}0 \\
(0)\end{array}$ & -2 & -1.7 & $\begin{array}{l}-4.0 * * * \\
(-5.548)\end{array}$ & -1.3 & $\begin{array}{l}-3.6 * * * \\
(-6.025)\end{array}$ & -1.7 & $\begin{array}{l}-3.9 * * * \\
(-5.092)\end{array}$ & -1.5 & $\begin{array}{l}-3.9 * * * \\
(-4.896)\end{array}$ \\
\hline $\begin{array}{l}\text { Prob. of } \\
\text { countercyclicality } \\
\text { Stability }\end{array}$ & “+” & $\begin{array}{l}75 \\
(0)\end{array}$ & 1 & 41.8 & $\begin{array}{c}39.2 \\
(0.728)\end{array}$ & 38.9 & $\begin{array}{c}40.5 \\
(-0.676)\end{array}$ & 38.5 & $\begin{array}{c}42.5 \\
(-1.011)\end{array}$ & 38.8 & $\begin{array}{c}41.3 \\
(-0.628)\end{array}$ \\
\hline Growth volatility & “_“ & $\begin{array}{l}50 \\
(25)\end{array}$ & 1 & 7.1 & $\begin{array}{c}4.3 \\
(-1.243)\end{array}$ & 8.1 & $\begin{array}{c}3.5^{*} \\
(-1.657)\end{array}$ & 3.3 & $\begin{array}{c}7.3^{* *} \\
(-2.533)\end{array}$ & 3.4 & $\begin{array}{c}9.6^{* *} \\
(2.184)\end{array}$ \\
\hline $\begin{array}{l}\text { Rel. growth } \\
\text { volatility }\end{array}$ & “_“ & $\begin{array}{l}25 \\
(0)\end{array}$ & 43 & 126.4 & $\begin{array}{c}17.1 \\
(-1.013)\end{array}$ & 36.8 & $\begin{array}{l}115.4^{*} \\
(1.653)\end{array}$ & 28.6 & $\begin{array}{l}123.1^{* *} \\
(2.034)\end{array}$ & 24.3 & $\begin{array}{l}133.9 * * \\
(2.157)\end{array}$ \\
\hline PI flows/GDP & “_“ & $\begin{array}{l}25 \\
(25)\end{array}$ & 0 & 0.9 & $\begin{array}{c}0.4^{* *} \\
(-2.480)\end{array}$ & 0.7 & $\begin{array}{c}0.7 \\
(-0.465)\end{array}$ & 0.7 & $\begin{array}{c}0.7 \\
(0.149)\end{array}$ & 0.7 & $\begin{array}{c}0.8 \\
(0.389)\end{array}$ \\
\hline $\begin{array}{l}\text { Inequality } \\
\text { Share of bottom } 20\end{array}$ & “+” & $\begin{array}{l}75 \\
(75)\end{array}$ & 1 & 5.0 & $\begin{array}{c}5.0 \\
(-0.186)\end{array}$ & 4.8 & $\begin{array}{c}5.4 * * \\
(2.160)\end{array}$ & 4.6 & $\begin{array}{l}5.8^{* * *} \\
(6.101)\end{array}$ & 4.2 & $\begin{array}{l}5.9 * * * \\
(8.486)\end{array}$ \\
\hline $\begin{array}{l}\text { Growth } \\
\text { 5-year average } \\
\text { growth }\end{array}$ & “+” & $\begin{array}{l}50 \\
(0)\end{array}$ & 0 & 4.3 & $\begin{array}{c}4.6 \\
(1.101)\end{array}$ & 4.6 & $\begin{array}{c}4.3 \\
(-0.935)\end{array}$ & 4.4 & $\begin{array}{c}4.1 \\
(-1.029)\end{array}$ & 4.2 & $\begin{array}{c}4.3 \\
(0.160)\end{array}$ \\
\hline Investment/ GDP & “+” & $\begin{array}{c}50 \\
(25)\end{array}$ & 0 & 22.0 & $\begin{array}{c}22.7 \\
(1.208)\end{array}$ & 22.2 & $\begin{array}{c}23.4^{*} \\
(1.676)\end{array}$ & 23.4 & $\begin{array}{c}21.9 * * \\
(-2.496)\end{array}$ & 22.6 & $\begin{array}{c}22.0 \\
(0.889)\end{array}$ \\
\hline
\end{tabular}

Notes: Differences are the average for more progressive tax systems minus the respective average of less progressive tax systems. All figures are in percent. See the text for variable definitions, data sources, and explanation of expected sign. For the percent of correct expectations, instances of no differences are counted as incorrect expectations. PI flows stands for portfolio investment. Figures in parentheses for comparisons are t-statistics and for "pct. Correct” refer to the percent of differences that have the correct expected sign and are statistically significant. * indicates significance at the $10 \%$-level, $* *$ indicates significance at the $5 \%$ level and $* * *$ indicates significance at the $1 \%$-level. 


\section{III.2 Constraints on Progressive Taxation}

The implementation of more progressive income taxation may be subject to three possible external constraints, the level of government expenditures, corporate tax rates, and capital account liberalization.

External constraints are not always associated with more progressive taxes. Increased government spending is associated with a more progressive tax system (Table 4). In comparison, though, countries with open capital accounts and lower corporate taxes tend to have less progressive personal tax systems than countries that are unconstrained.

Industrializing economies may face stricter constraints than theory suggests. For instance, capital account openness and lower corporate taxes may reflect constraints on all income taxes. With a fixed level of government expenditures, this should result in larger budget deficits. As a result, governments may look for additional revenue sources, particularly consumption taxes.

We test this argument. Specifically, we consider total revenue relative to GDP, fiscal balances, and the level of the VAT in constrained and unconstrained instances to see if constraints are associated with less spending elsewhere, wider budget deficits, and higher VATs and payroll taxes. Increased government spending is associated with a larger VAT and higher payroll taxes, but also greater budget deficits, despite higher revenues. Furthermore, under capital mobility we find a lower VAT, but smaller budget deficits, higher revenue generation, and higher government consumption expenditures, which seem to be financed, among other things, out of higher payroll taxes. Finally, lower corporate taxes are associated with smaller deficits despite lower VATs and fewer revenues, which may be compensated for by higher payroll taxes and decreased government spending (Table 5).

Our figures suggest a few important results. First, external liberalization seems to impose an additional constraint on tax design, as policymakers may have to reduce budget deficits in order to attract foreign capital (Blecker, 1999). Second, in the same vein, the reduction of budget deficits under capital account liberalization are associated with greater revenue and not necessarily decreased spending, although spending may become more pro-cyclical (Blecker, 1999). Third, policymakers seem to shift from progressive income taxation to more regressive payroll taxes to compensate for the loss of corporate incomes taxes, suggesting that constraints on corporate income taxes may also hold to some degree for personal income taxes. The overarching lesson is that policymakers tend to find ways to increase revenue, but do not seem to do so by raising the progressiveness of income taxation, especially in open economies. 
Table 4

Progressiveness of Personal Income Taxation with and without External Constraints

\begin{tabular}{|c|c|c|c|c|c|c|c|c|c|c|c|}
\hline & \multirow{2}{*}{$\begin{array}{c}\text { Exp. Sign } \\
\text { of } \\
\text { difference } \\
\end{array}$} & \multirow[t]{2}{*}{$\begin{array}{c}\text { Pct. } \\
\text { Correct }\end{array}$} & \multirow[t]{2}{*}{$\begin{array}{l}\text { Avg. } \\
\text { difference }\end{array}$} & \multicolumn{2}{|c|}{$\begin{array}{l}\text { Top marginal tax rate } \\
\text { (Fraser) }\end{array}$} & \multicolumn{2}{|c|}{$\begin{array}{l}\text { Top marginal tax rate } \\
\text { (AEI) }\end{array}$} & \multicolumn{2}{|c|}{ Avg. tax rate } & \multicolumn{2}{|c|}{ Med. Tax rate } \\
\hline & & & & $\begin{array}{c}\text { With } \\
\text { constraint }\end{array}$ & $\begin{array}{l}\text { Without } \\
\text { constraint }\end{array}$ & $\begin{array}{c}\text { With } \\
\text { constraint }\end{array}$ & $\begin{array}{l}\text { Without } \\
\text { constraint }\end{array}$ & $\begin{array}{c}\text { With } \\
\text { constraint }\end{array}$ & $\begin{array}{l}\text { Without } \\
\text { constraint }\end{array}$ & $\begin{array}{c}\text { With } \\
\text { constraint }\end{array}$ & $\begin{array}{l}\text { Without } \\
\text { constraint }\end{array}$ \\
\hline $\begin{array}{l}\text { Government } \\
\text { spending/GDP }\end{array}$ & “-_“ & $\begin{array}{c}75 \\
(75)\end{array}$ & -2 & 42.3 & $\begin{array}{c}42.5 \\
(-0.209)\end{array}$ & 43.3 & $\begin{array}{l}41.1 * * * \\
(3.208)\end{array}$ & 29.0 & $\begin{array}{l}25.5 * * * \\
(5.097)\end{array}$ & 29.0 & $\begin{array}{l}24.9 * * * \\
(5.639)\end{array}$ \\
\hline $\begin{array}{l}\text { Capital } \\
\text { account } \\
\text { open/close }\end{array}$ & “-_“ & $\begin{array}{c}0 \\
(0)\end{array}$ & 12 & 26.4 & $\begin{array}{l}48.0 * * * \\
(24.229)\end{array}$ & 33.0 & $\begin{array}{l}44.7 * * * \\
(13.181)\end{array}$ & 21.8 & $\begin{array}{l}28.8^{* * *} \\
(11.206)\end{array}$ & 21.6 & $\begin{array}{l}28.5^{* * *} \\
(10.716)\end{array}$ \\
\hline $\begin{array}{l}\text { Avg. } \\
\text { corporate tax } \\
\text { rate }\end{array}$ & “_“ & $\begin{array}{c}0 \\
(0)\end{array}$ & 13 & 35.6 & $\begin{array}{l}51.1^{* * *} \\
(16.388)\end{array}$ & 35.7 & $\begin{array}{l}50.3^{* * *} \\
(18.879)\end{array}$ & 22.7 & $\begin{array}{l}32.8 * * * \\
(18.752)\end{array}$ & 22.4 & $\begin{array}{l}32.5 * * * \\
(17.994)\end{array}$ \\
\hline $\begin{array}{l}\text { Median corp. } \\
\text { tax rate }\end{array}$ & “_““ & $\begin{array}{c}0 \\
(0)\end{array}$ & 13 & 35.5 & $\begin{array}{l}51.1^{* * *} \\
(16.368)\end{array}$ & 35.6 & $\begin{array}{l}50.3^{* * *} \\
(18.859)\end{array}$ & 22.7 & $\begin{array}{l}32.7 * * * \\
(18.869)\end{array}$ & 22.4 & $\begin{array}{l}32.6 * * * \\
(18.141)\end{array}$ \\
\hline
\end{tabular}

Notes: Differences are the average tax rate without constraint minus the tax rate with constraints. Constraints are high government spending, open capital accounts, and low corporate taxes. All figures are in percent. See the text for variable definitions, data sources, and explanation of expected sign. For the percent of correct expectations, instances of no differences are counted as incorrect expectations. PI flows stands for portfolio investment. Figures in parentheses for comparisons are t-statistics and for "pct. Correct" refer to the percent of differences that have the correct expected sign and are statistically significant. * indicates significance at the $10 \%$-level, ** indicates significance at the 5\%-level and *** indicates significance at the $1 \%$-level. 
Table 5

Government Revenue, Fiscal Balances and Value Added Taxes with and without External Constraints

\begin{tabular}{|c|c|c|c|c|c|c|c|c|c|c|}
\hline & \multicolumn{2}{|c|}{ Taxes/GDP } & \multicolumn{2}{|c|}{ Fiscal balance/GDP } & \multicolumn{2}{|c|}{ VAT rate } & \multicolumn{2}{|c|}{$\begin{array}{c}\text { Government } \\
\text { consumption } \\
\text { spending/GDP }\end{array}$} & \multicolumn{2}{|c|}{ Payroll taxes } \\
\hline & $\begin{array}{l}\text { With } \\
\text { const. }\end{array}$ & $\begin{array}{l}\text { Without } \\
\text { const. }\end{array}$ & $\begin{array}{l}\text { With } \\
\text { const. }\end{array}$ & $\begin{array}{l}\text { Without } \\
\text { const. }\end{array}$ & $\begin{array}{l}\text { With } \\
\text { const. }\end{array}$ & $\begin{array}{c}\text { Without } \\
\text { const. }\end{array}$ & $\begin{array}{l}\text { With } \\
\text { const. }\end{array}$ & $\begin{array}{l}\text { Without } \\
\text { const. }\end{array}$ & $\begin{array}{l}\text { With } \\
\text { const. }\end{array}$ & $\begin{array}{c}\text { Without } \\
\text { const. }\end{array}$ \\
\hline $\begin{array}{l}\text { Government } \\
\text { spending/ } \\
\text { GDP }\end{array}$ & 28.5 & $\begin{array}{l}13.1^{* * *} \\
(45.683)\end{array}$ & -4.1 & $\begin{array}{l}-1.8 * * * \\
(-9.832)\end{array}$ & 15.6 & $\begin{array}{l}11.1^{* * *} \\
(8.303)\end{array}$ & 13.7 & $\begin{array}{c}5.4^{* * *} \\
(21.662)\end{array}$ & 6.5 & $\begin{array}{l}3.5 * * * \\
(6.645)\end{array}$ \\
\hline $\begin{array}{l}\text { Capital } \\
\text { account } \\
\text { open/close }\end{array}$ & 22.9 & $\begin{array}{l}20.9 * * * \\
(-3.447)\end{array}$ & -1.3 & $\begin{array}{l}-3.6^{* * * *} \\
(-6.984)\end{array}$ & 12.7 & $\begin{array}{l}14.7^{* * *} \\
(3.894)\end{array}$ & 12.0 & $\begin{array}{l}9.6^{* * *} \\
(5.085)\end{array}$ & 10.5 & $\begin{array}{c}9.5 * * * \\
(-3.703)\end{array}$ \\
\hline $\begin{array}{l}\text { Avg. } \\
\text { corporate tax } \\
\text { rate }\end{array}$ & 21.9 & $\begin{array}{c}24.2^{* * *} \\
(3.394)\end{array}$ & -2.0 & $\begin{array}{l}-4.0^{* * *} \\
(-6.029)\end{array}$ & 13.8 & $\begin{array}{l}15.5^{* * *} \\
(3.078)\end{array}$ & 8.9 & $\begin{array}{c}9.8^{*} \\
(1.633)\end{array}$ & 10.5 & $\begin{array}{c}9.5 \\
(-1.333)\end{array}$ \\
\hline $\begin{array}{l}\text { Median corp. } \\
\text { tax rate }\end{array}$ & 21.9 & $\begin{array}{c}24.1^{* * * *} \\
(3.248)\end{array}$ & -2.0 & $\begin{array}{l}-4.1 * * * \\
(-6.174)\end{array}$ & 13.8 & $\begin{array}{l}15.5^{* * * *} \\
(3.106)\end{array}$ & 9.0 & $\begin{array}{c}10.0 * \\
(1.771)\end{array}$ & 10.5 & $\begin{array}{c}9.6 \\
(1.255)\end{array}$ \\
\hline
\end{tabular}

Notes: Differences are the average tax rate without constraint minus the tax rate with constraints. Constraints are high government spending, open capital accounts, and low corporate taxes. All figures are in percent. See the text for variable definitions, data sources, and explanation of expected sign. For the percent of correct expectations, instances of no differences are counted as incorrect expectations. PI flows stands for portfolio investment. Figures in parentheses for comparisons are t-statistics and for "pct. Correct” refer to the percent of differences that have the correct expected sign and are statistically significant. * indicates significance at the $10 \%$-level, ** indicates significance at the 5\%-level and *** indicates significance at the $1 \%$-level. 


\section{III.3 Value Added Taxes and Economic Stability}

Countries may look towards the implementation of consumption taxes to overcome another constraint - ineffective tax collection. The short-term link between a VAT and economic stability seems weaker than in the case of personal income taxes (Table 6). Volatility and capital inflows are greater when the VAT is higher and the size difference between high-tax and low-tax regimes is greater than is the case for different personal income tax regimes. In contrast, the difference in relative volatility is smaller in the VAT case than in the personal income tax case. Also, revenues are higher with a larger VAT and the size of the difference is greater than in the case of progressive taxes. Moreover, budget deficits are again greater with higher taxes, but the difference between high-tax and low-tax regimes is about half the difference that it is for the comparison of personal income tax regimes. In the same vein, countries with higher VATs are less likely than countries with lower VATs to engage in countercyclical fiscal policy, although the difference is statistically insignificant. Countries lose some of the short-term stability benefits that they may enjoy under progressive income taxation, when they switch to a VAT.

A similar conclusion may be drawn with respect to longer-term links between taxes and economic stability. A higher VAT is associated with less income inequality and on average about the same growth rate, but less investment. The difference in investment is also greater between high VAT and low VAT regimes than it is for personal income taxes (Table 6).

Table 6

Revenue, Capital Flows, Growth, and Stability under Different VAT Regimes

\begin{tabular}{|c|c|c|c|c|}
\hline & $\begin{array}{l}\text { Exp. Sign of } \\
\text { difference }\end{array}$ & Below median & Above median & Difference \\
\hline \multicolumn{5}{|l|}{$\begin{array}{l}\text { No condition } \\
\text { Government finances }\end{array}$} \\
\hline Taxes/GDP & “+” & 19.5 & $\begin{array}{c}24.7 \\
(6.330)\end{array}$ & 5 \\
\hline Govt. balance/GDP & “+” & -2.4 & $\begin{array}{c}-3.0 \\
(1.432)\end{array}$ & -1 \\
\hline $\begin{array}{l}\text { Prob. of } \\
\text { countercylicality } \\
\text { Stability }\end{array}$ & “+” & 33.0 & $\begin{array}{c}31.0 \\
(-0.616)\end{array}$ & -2 \\
\hline Growth volatility & “_“ & 3.1 & $\begin{array}{l}9.6^{* * *} \\
(2.594)\end{array}$ & 7 \\
\hline Rel. growth volatility & “_“ & 138.7 & $\begin{array}{l}154.9 \\
(0.137)\end{array}$ & 16 \\
\hline PI flows/GDP & “_-“ & 0.3 & $\begin{array}{l}0.9 * * * \\
(3.828)\end{array}$ & 1 \\
\hline \multicolumn{5}{|l|}{ Inequality } \\
\hline Share of bottom 20 & “+” & 4.5 & $\begin{array}{l}5.5^{* * *} \\
(5.818)\end{array}$ & 1 \\
\hline \multicolumn{5}{|l|}{ Growth } \\
\hline 5-year average growth & “+” & 4.0 & $\begin{array}{c}3.8 \\
(-0.593)\end{array}$ & 0 \\
\hline Investment/GDP & “+” & 21.3 & $\begin{array}{c}20.4^{*} \\
(-1.922)\end{array}$ & -1 \\
\hline $\begin{array}{l}\text { PI inflows present } \\
\text { Government finances }\end{array}$ & & & & \\
\hline
\end{tabular}




\begin{tabular}{|c|c|c|c|c|}
\hline Taxes/GDP & “+” & 20.0 & $\begin{array}{c}24.4 \\
(4.817)\end{array}$ & 4 \\
\hline Govt. balance/GDP & “+” & -2.2 & $\begin{array}{c}-3.0 \\
(-1.562)\end{array}$ & -1 \\
\hline $\begin{array}{l}\text { Prob. of } \\
\text { countercyclicality } \\
\text { Stability }\end{array}$ & “+” & 42.3 & $\begin{array}{c}37.4 \\
(-1.180)\end{array}$ & -5 \\
\hline Growth volatility & “__“ & 3.1 & $\begin{array}{l}10.5^{* *} \\
(2.362)\end{array}$ & 7 \\
\hline Rel. growth volatility & “__“ & 156.6 & $\begin{array}{c}82.7 \\
(-0.551)\end{array}$ & -74 \\
\hline PI flows/GDP & “_“ & 0.3 & $\begin{array}{l}0.9 * * * \\
(3.828)\end{array}$ & 1 \\
\hline Inequality & & & & \\
\hline Share of bottom 20 & “+” & 4.5 & $\begin{array}{l}5.6 * * * \\
(5.270)\end{array}$ & 1 \\
\hline $\begin{array}{l}\text { Growth } \\
\text { 5-year average growth }\end{array}$ & “+” & 4.2 & $\begin{array}{c}4.1 \\
(-0.024)\end{array}$ & 0 \\
\hline Investment/GDP & “+” & 22.3 & $\begin{array}{l}20.7^{* * *} \\
(-2.727)\end{array}$ & -2 \\
\hline
\end{tabular}

Notes: All figures are in percent. See the text for variable definitions, data sources, and explanation of expected sign. The expected signs refer to the progressive income taxation comparison and are included here only for comparison purposes. Figures in parentheses for comparisons are t-statistics and for "pct. Correct" refer to the percent of differences that have the correct expected sign and are statistically significant. * indicates significance at the $10 \%$ level, ** indicates significance at the $5 \%$-level and $* * *$ indicates significance at the $1 \%$-level.

Would our conclusions change if we combined progressive personal income taxes with a VAT? Such a combination may help improve the short-term stability outlook, compared to a situation of solely progressive taxes (Table 7). The relative output volatility increases in two out of four cases. And, in three out of four cases, the relative output volatility is lower when progressive personal income taxes are combined with a high VAT, compared to a combination with a low VAT. ${ }^{5}$ Also, a high VAT in combination with progressive income taxes give countries more room to engage in countercyclical fiscal policy. And, the combination of a high VAT with progressive income taxation seems to improve the overall short-term stability outlook, if relative volatility is the most appropriate indicator of macro economic stability. Finally, the combination of progressive income taxes with a high VAT improves the growth prospects and reduces inequality in three out of four cases.

The combination of progressive income taxes with a low VAT offers less of an improvement. On the plus side, it reduces absolute volatility and short-term capital inflows, but it increases relative output volatility and lowers the chance of countercyclical fiscal policy. Moreover, inequality and growth worsen or are unchanged, when progressive income taxes are combined with a low VAT.

The results thus suggest that the outlook for economic volatility seems to improve when progressive personal income taxes are combined with a high VAT, while the same is not true when progressive personal income taxes are combined with a low VAT.

\footnotetext{
${ }^{5}$ Authors' calculations are not shown here, but are available upon request.
} 
Table 7

Revenue, Capital Flows, Growth, and Stability under Different Personal Income Tax Regimes with VAT

\begin{tabular}{|c|c|c|c|c|c|c|c|c|c|c|c|c|c|}
\hline & \multirow[t]{3}{*}{$\begin{array}{l}\text { Improvmt. } \\
\text { if sign... }\end{array}$} & \multicolumn{4}{|c|}{$\begin{array}{c}\text { Difference to high personal income taxes } \\
\text { alone }\end{array}$} & \multicolumn{2}{|c|}{$\begin{array}{l}\text { Top marginal tax } \\
\text { rate (Fraser) }\end{array}$} & \multicolumn{2}{|c|}{$\begin{array}{l}\text { Top marginal tax } \\
\text { rate (AEI) }\end{array}$} & \multicolumn{2}{|c|}{ Avg. tax rate } & \multicolumn{2}{|c|}{ Median tax rate } \\
\hline & & With hig & VAT & With lov & VAT & $\begin{array}{l}\text { With } \\
\text { high } \\
\text { VAT }\end{array}$ & $\begin{array}{l}\text { With } \\
\text { low } \\
\text { VAT }\end{array}$ & $\begin{array}{l}\text { With high } \\
\text { VAT }\end{array}$ & $\begin{array}{l}\text { With } \\
\text { low } \\
\text { VAT }\end{array}$ & $\begin{array}{l}\text { With } \\
\text { high } \\
\text { VAT }\end{array}$ & $\begin{array}{l}\text { With } \\
\text { low } \\
\text { VAT }\end{array}$ & $\begin{array}{l}\text { With } \\
\text { high } \\
\text { VAT }\end{array}$ & $\begin{array}{l}\text { With } \\
\text { low } \\
\text { VAT }\end{array}$ \\
\hline & & Incidence & Avg. & Incidence & Avg. & & & & & & & & \\
\hline \multicolumn{14}{|l|}{$\begin{array}{l}\text { Government } \\
\text { finances }\end{array}$} \\
\hline Taxes/GDP & “+” & 100 & 1 & 0 & -5 & 0.5 & -2.5 & 1.5 & -5.0 & 1.3 & -5.4 & 1.4 & -6.0 \\
\hline Govt. balance/GDP & “+” & 25 & 0 & 50 & 0 & -0.2 & 0.8 & 0.2 & -0.5 & 0.0 & 0.1 & 0.0 & 0.0 \\
\hline $\begin{array}{l}\text { Prob. of } \\
\text { countercyclicality } \\
\text { Stability }\end{array}$ & “+” & 75 & 0 & 25 & 1 & -0.7 & 3.8 & 0.9 & -0.7 & 0.6 & 0.0 & 0.7 & -0.8 \\
\hline Growth volatility & “_” & 0 & 1 & 100 & -2 & 0.4 & -1.6 & 0.2 & -0.6 & 0.8 & -3.0 & 1.2 & -4.4 \\
\hline $\begin{array}{l}\text { Rel. growth } \\
\text { volatility }\end{array}$ & “_“ & 50 & 4 & 25 & 20 & 49.8 & 101.3 & 106.7 & 140.9 & 139.3 & 140.5 & 151.4 & 140.5 \\
\hline $\begin{array}{l}\text { PI flows/GDP } \\
\text { Inequality }\end{array}$ & “-” & 0 & 0 & 100 & 0 & 0.1 & -0.2 & 0.2 & -0.5 & 0.2 & -0.4 & 0.2 & -0.5 \\
\hline $\begin{array}{l}\text { Share of bottom } 20 \\
\text { Growth }\end{array}$ & “+” & 75 & 0 & 0 & -1 & 0.0 & -0.1 & 0.2 & -0.6 & 0.3 & -0.7 & 0.3 & -0.8 \\
\hline $\begin{array}{l}\text { 5-year average } \\
\text { growth }\end{array}$ & “+” & 75 & 0 & 0 & 0 & 0.1 & -0.4 & 0.0 & 0.0 & 0.1 & -0.3 & 0.1 & -0.4 \\
\hline $\begin{array}{l}\text { Investment/ } \\
\text { GDP }\end{array}$ & “+” & 75 & 0 & 25 & 1 & 21.3 & 22.0 & 22.8 & 20.9 & 21.8 & 21.1 & 22.2 & 21.1 \\
\hline
\end{tabular}

Notes: All figures are in percent. See the text for variable definitions, data sources, and explanation of expected sign. The expected signs refer to the comparison with progressive income taxation alone. A positive sign indicates that the measure is greater for the combined taxes than for progressive personal income taxes alone. Incidence refers to the number of instances, in which the difference to just progressive taxation improves the stability outlook. 


\section{Multivariate Analysis}

We test the three basic relationships using multivariate analyses. Specifically, we consider first the link between economic stability and a number of economic variables, including tax progressives. Next, we analyze the determinants of tax progressiveness. And finally, we see if the addition of a VAT to progressive income taxation has any bearing on economic stability.

\section{IV.1 Progressive Taxation and Economic Stability}

Our first analysis focuses on the connection between progressive taxation and economic stability. The dependent variable is economic stability, defined as the growth rate relative to the standard deviation of growth for that country over the entire sample period.

The explanatory variables are investment, income inequality, capital inflows, and a measure for fiscal policy. The measure for fiscal policy combines growth and changes in fiscal balances into a continuous variable, defined as follows:

$$
\text { Countercyclicality }=\mid \text { Growth }+\frac{\sigma g}{\sigma f} \text { fiscalbalance } \mid
$$

where fiscalbalance denotes the growth rate of the fiscal balance relative to GDP, $\sigma_{\mathrm{g}}$ is the standard deviation of the growth rate and $\sigma_{\mathrm{f}}$ is the standard deviation of the growth rate of the fiscal balance relative to GDP. If growth and fiscal balances move in the same direction, the country engages in countercyclical policies and the variable should show larger values. The opposite is true if both growth rates move in opposite directions. The variable is also constructed, such that the conditional variances of the two components are the same.

The regression analysis also includes measures for tax progressiveness. These variables control for influences of tax policy on variables that are not included in the analysis, but that could have a potential impact on economic stability, such as human capital formation.

The hypotheses to be tested are straightforward. Economic stability is expected to be positively related to investment, countercyclicality, capital inflows and progressive taxation and negatively related to inequality. In this vein, the fate of an economy may depend to some degree on the potential volatility of short-term capital flows, which could increase if countercyclical policy results in larger budget deficits that are not offset by greater domestic saving.

The analysis employs a dynamic OLS approach (Stock and Watson, 1993). This approach controls for the fact that many macro economic series, e.g. tax rates, are non-stationary. The model uses the first difference with no lag and the first lagged value of each explanatory variable. The estimation is robust, when additional lags and leads for the changes of the explanatory variables are included. The coefficients on the differences capture short-term deviations from long-term relationship, while the levels measure these long-term links. 
Importantly, economic stability is systematically connected to countercyclical policy. ${ }^{6}$ The first regression in table 8 presents the baseline case without controls for progressive taxation. All variables are statistically insignificant or have the expected sign. Economic stability in the short-run is positively correlated with investment, capital inflows and countercyclical fiscal policy. In the long-run, investment is no longer statistically significant, which highlights the short-run importance of investment for business cycle movements. The biggest short-run and long-run contribution from progressive taxation to economic stability thus emerges from a country's ability to engage in countercyclical fiscal policy, although greater deficits may expose countries to increased volatility from more short-term capital inflows.

When progressive taxation variables are included, they have a small adverse long-run impact on economic stability. While this points to potentially relevant trade-offs when considering progressive taxation as an economic stabilization tool, it is important to note that the estimated coefficient is relatively small. At the average, an increase of one standard deviation of the median tax rate, for instance, results in a $8.5 \%$ reduction of economic stability, while a onestandard deviation increase in countercyclical policy increases stability by $17.1 \%$ in the long-run and by $17.2 \%$ in the short-run. That is, the ability of economies to engage in countercyclical fiscal policy with more progressive taxation may outweigh potentially adverse effects from more progressive taxation in terms of economic stability.

\section{Table 8}

\section{Regression Analysis of Macro Economic Stability}

\begin{tabular}{|c|c|c|c|c|c|}
\hline Explanatory variable & $\begin{array}{c}\text { Baseline } \\
(1)\end{array}$ & $\begin{array}{c}\text { Top marginal tax } \\
\text { rate (Frazer) }\end{array}$ & $\begin{array}{l}\text { Top marginal } \\
\text { tax rate (AEI) }\end{array}$ & $\begin{array}{l}\text { Avg. tax } \\
\text { rate }\end{array}$ & $\begin{array}{l}\text { Median } \\
\text { tax rate }\end{array}$ \\
\hline Investment to GDP & $0.210^{* * *}$ & $0.205^{* * *}$ & $0.210^{* * *}$ & $0.210 * * *$ & $0.210^{* * *}$ \\
\hline (differenced) & 0.017 & 0.017 & 0.016 & 0.016 & 0.016 \\
\hline Indicator for & $0.033^{* * *}$ & $0.032^{* * *}$ & $0.032 * * *$ & $0.031^{* * *}$ & $0.031^{* * *}$ \\
\hline $\begin{array}{l}\text { countercyclicality } \\
\text { (differenced) }\end{array}$ & 0.009 & 0.009 & 0.009 & 0.009 & 0.009 \\
\hline Inc. share of bottom $20 \%$ & -0.02 & -0.00 & -0.00 & -0.00 & -0.01 \\
\hline (differenced) & 0.053 & 0.054 & 0.054 & 0.054 & 0.054 \\
\hline Capital inflows to GDP & $0.043^{* * *}$ & $0.044 * * *$ & $0.045^{* * *}$ & $0.045 * * *$ & $0.045^{* * *}$ \\
\hline (differenced) & 0.016 & 0.016 & 0.016 & 0.016 & 0.016 \\
\hline $\begin{array}{l}\text { Top marginal tax rate } \\
\text { (Frazer) (differenced) }\end{array}$ & & $\begin{array}{c}-0.05^{* *} \\
0.030\end{array}$ & & & \\
\hline $\begin{array}{l}\text { Top marginal tax rate } \\
\text { (AEI) (differenced) }\end{array}$ & & & $\begin{array}{l}-0.00 \\
0.008\end{array}$ & & \\
\hline $\begin{array}{l}\text { Average tax rate } \\
\text { (differenced) }\end{array}$ & & & & $\begin{array}{l}-0.01 \\
0.010\end{array}$ & \\
\hline $\begin{array}{l}\text { Median tax rate } \\
\text { (differenced) }\end{array}$ & & & & & $\begin{array}{l}-0.01 \\
0.010\end{array}$ \\
\hline Investment to GDP & -0.00 & -0.01 & -0.01 & -0.01 & -0.01 \\
\hline (lagged) & 0.012 & 0.012 & 0.012 & 0.012 & 0.012 \\
\hline Indicator for & $0.039 * * *$ & $0.037 * * *$ & $0.036 * * *$ & $0.036 * * *$ & $0.036^{* * *}$ \\
\hline countercyclicality (lagged) & 0.013 & 0.013 & 0.013 & 0.013 & 0.013 \\
\hline
\end{tabular}

\footnotetext{
${ }^{6}$ The results are robust, when the continuous fiscal policy variable is replaced by the indicator variable for countercyclical fiscal policy discussed in the previous section.
} 


\begin{tabular}{lccccc}
\hline Inc. share of bottom 20\% & 0.008 & 0.048 & 0.047 & 0.031 & 0.024 \\
(lagged) & 0.062 & 0.065 & 0.063 & 0.063 & 0.063 \\
Capital inflows to GDP & $0.049^{* * *}$ & $0.049^{* *}$ & $0.052^{* *}$ & $0.051^{* *}$ & $0.051^{* *}$ \\
(lagged) & 0.023 & 0.023 & 0.023 & 0.023 & 0.023 \\
Top marginal tax rate & & $-0.01^{* *}$ & & & \\
(Frazer) (lagged) & & 0.006 & & & \\
Top marginal tax rate & & & $-0.01^{* *}$ & & \\
(AEI) (lagged) & & 0.005 & & $-0.01^{* *}$ & \\
Average tax rate (lagged) & & & 0.008 & \\
& & & & & $-0.01^{* *}$ \\
Median tax rate (lagged) & & & & & 0.008 \\
& $1.162^{* * *}$ & $1.628^{* * *}$ & $1.614^{* * *}$ & $1.671^{* * *}$ & $1.643^{* * *}$ \\
Constant & 0.437 & 0.487 & 0.474 & 0.481 & 0.483 \\
& & & & & \\
& 287 & 287 & 287 & 287 & 287 \\
$\mathrm{~N}$ & 0.466 & 0.477 & 0.479 & 0.478 & 0.477 \\
R-Squared & & & & & \\
\hline
\end{tabular}

Notes: See text for explanation of variables and sources. All regressions are conducted with country fixed effects. Analysis excludes industrialized economies. Figures in parentheses are standard errors. ${ }^{* * *}$ denotes significance at $1 \%$-level, ${ }^{* *}$ denotes significance at 5\%-level, and $*$ denotes significance at $10 \%$-level.

\section{IV.2 The Determinants of Progressive Taxation}

Next, we test whether the potential constraints on the implementation of progressive taxation, as the univariate analysis suggests. Following standard tax determination models, the dependent variables are the four progressive tax measures and the explanatory variables include government spending, corporate tax rates and capital inflows. The regression is again estimated using a dynamic OLS approach with the first difference with no lag and the lagged value of the explanatory variables.

The implementation of progressive taxes indeed seems to be constrained by government spending (table 9). This systematic connection holds only in the long-run, but not in the shortrun. This suggests that governments looking for additional revenue may be limited in their ability to increase the progressiveness of personal income taxation if spending is high, especially since spending may not change much over time, thus explaining the persistence of this constraint.

Furthermore, as discussed before, greater openness may create two pressure points on tax design. International corporate tax competition may lead policymakers to seek more revenue from less mobile labor. In addition, reduced revenue from fewer tariffs and possibly higher expenditures to attract capital also lead policymakers to look for more revenue elsewhere. The results, though, indicate that increased capital account liberalization may be associated with growing pressures to lower taxes, both for individuals and corporations. In particular, increased capital inflows are associated with less progressive personal income taxation (Table 9), at least with lower top marginal tax rates in the long-run. In addition, lower corporate tax rates go along with lower personal income tax rates. The impact again seems to be larger on top marginal tax rates than on average and median tax rates. These results indicate that countries may decide, 
possibly for non-economic reasons, to reduce their overall tax rates, especially at the top end of the income scale, when a country becomes more economically integrated.

Table 9

Regression Analysis of the Determinants of Tax Progressiveness

\begin{tabular}{|c|c|c|c|c|c|c|c|c|}
\hline \multirow{3}{*}{$\begin{array}{l}\text { Govt. } \\
\text { spending } \\
\text { (differenced). } \\
\text { GDP growth } \\
\text { (differenced) }\end{array}$} & \multicolumn{2}{|c|}{$\begin{array}{l}\text { Top marginal tax } \\
\text { rate (Fraser) }\end{array}$} & \multicolumn{2}{|c|}{$\begin{array}{l}\text { Top marginal tax } \\
\text { rate (AEI) }\end{array}$} & \multicolumn{2}{|c|}{ Avg. tax rate } & \multicolumn{2}{|c|}{ Median tax rate } \\
\hline & $\begin{array}{l}-0.02 \\
(0.113)\end{array}$ & $\begin{array}{c}-0.02 \\
(0.112)\end{array}$ & $\begin{array}{l}-0.08 \\
(0.115)\end{array}$ & $\begin{array}{c}-0.08 \\
(0.114)\end{array}$ & $\begin{array}{c}0.037 \\
(0.077)\end{array}$ & $\begin{array}{c}0.037 \\
(0.076)\end{array}$ & $\begin{array}{c}0.028 \\
(0.080)\end{array}$ & $\begin{array}{c}0.027 \\
(0.080)\end{array}$ \\
\hline & $\begin{array}{c}0.002 \\
(0.014)\end{array}$ & & $\begin{array}{l}-0.00 \\
(0.014)\end{array}$ & $\begin{array}{l}-0.00 \\
(0.014)\end{array}$ & $\begin{array}{l}-0.00 \\
(0.009)\end{array}$ & $\begin{array}{l}-0.00 \\
(0.009)\end{array}$ & $\begin{array}{c}-0.00 \\
(0.010)\end{array}$ & $\begin{array}{l}-0.00 \\
(0.010)\end{array}$ \\
\hline $\begin{array}{l}\text { Capital } \\
\text { inflows to } \\
\text { GDP } \\
\text { (differenced) }\end{array}$ & $\begin{array}{l}-0.28^{* *} \\
(0.140)\end{array}$ & $\begin{array}{c}0.002 \\
(0.014)\end{array}$ & $\begin{array}{c}-0.10 \\
(0.142)\end{array}$ & $\begin{array}{c}-0.14 \\
(0.142)\end{array}$ & $\begin{array}{c}-0.04 \\
(0.095)\end{array}$ & $\begin{array}{l}-0.06 \\
(0.094)\end{array}$ & $\begin{array}{c}-0.04 \\
(0.099)\end{array}$ & $\begin{array}{c}-0.07 \\
(0.099)\end{array}$ \\
\hline $\begin{array}{l}\text { Avg. corp. } \\
\text { tax rate } \\
\text { (differenced) }\end{array}$ & $\begin{array}{c}0.330 * * * \\
(0.126)\end{array}$ & & $\begin{array}{c}0.444^{* * *} \\
(0.128)\end{array}$ & & $\begin{array}{c}0.425^{* * *} \\
(0.085)\end{array}$ & & $\begin{array}{c}0.406^{* * *} \\
(0.090)\end{array}$ & \\
\hline $\begin{array}{l}\text { Median corp. } \\
\text { tax rate } \\
\text { (differenced) }\end{array}$ & & $\begin{array}{c}0.328^{* * * *} \\
(0.123)\end{array}$ & & $\begin{array}{c}0.440^{* * *} \\
(0.126)\end{array}$ & & $\begin{array}{c}0.422^{* * *} \\
(0.084)\end{array}$ & & $\begin{array}{c}0.407 * * * \\
(0.088)\end{array}$ \\
\hline $\begin{array}{l}\text { Govt. } \\
\text { spending to } \\
\text { GDP (lagged) }\end{array}$ & $\begin{array}{c}0.326^{* * *} \\
(0.099)\end{array}$ & $\begin{array}{c}0.314 * * * \\
(0.098)\end{array}$ & $\begin{array}{c}0.257^{* *} \\
(0.100)\end{array}$ & $\begin{array}{c}0.247^{* *} \\
(0.100)\end{array}$ & $\begin{array}{c}0.182 * * * \\
(0.067)\end{array}$ & $\begin{array}{c}0.174 * * * \\
(0.066\end{array}$ & $\begin{array}{c}0.148^{* *} \\
(0.070\end{array}$ & $\begin{array}{c}0.140^{* *} \\
(0.070\end{array}$ \\
\hline $\begin{array}{l}\text { GDP growth } \\
\text { (lagged) }\end{array}$ & $\begin{array}{c}0.001 \\
(0.015)\end{array}$ & $\begin{array}{c}0.000 \\
(0.015)\end{array}$ & $\begin{array}{c}-0.00 \\
(0.015)\end{array}$ & $\begin{array}{l}-0.00 \\
(0.015)\end{array}$ & $\begin{array}{c}-0.00 \\
(0.010)\end{array}$ & $\begin{array}{l}-0.00 \\
(0.010)\end{array}$ & $\begin{array}{c}-0.00 \\
(0.011)\end{array}$ & $\begin{array}{l}-0.00 \\
(0.011)\end{array}$ \\
\hline $\begin{array}{l}\text { Avg. corp. } \\
\text { tax rate } \\
\text { (lagged) }\end{array}$ & $\begin{array}{c}0.740^{* * *} \\
(0.069)\end{array}$ & & $\begin{array}{c}0.921^{* * * *} \\
(0.070)\end{array}$ & & $\begin{array}{c}0.556^{* * *} \\
(0.047)\end{array}$ & & $\begin{array}{c}0.537 * * * \\
(0.049)\end{array}$ & \\
\hline $\begin{array}{l}\text { Med. corp. } \\
\text { tax rate } \\
\text { (lagged) }\end{array}$ & & $\begin{array}{c}0.754^{* * *} \\
(0.068)\end{array}$ & & $\begin{array}{c}0.925^{* * *} \\
(0.070)\end{array}$ & & $\begin{array}{c}0.560^{* * * *} \\
(0.046)\end{array}$ & & $\begin{array}{c}0.543^{* * *} \\
(0.049)\end{array}$ \\
\hline $\begin{array}{l}\text { Capital } \\
\text { inflows to } \\
\text { GDP (lagged) }\end{array}$ & $\begin{array}{c}-0.53^{* * *} \\
(0.203)\end{array}$ & $\begin{array}{c}-0.60 * * * \\
(0.203)\end{array}$ & $\begin{array}{l}-0.45^{* *} \\
(0.206)\end{array}$ & $\begin{array}{l}-0.52^{* *} \\
(0.207)\end{array}$ & $\begin{array}{c}-0.15 \\
(0.138)\end{array}$ & $\begin{array}{c}-0.19 \\
(0.138)\end{array}$ & $\begin{array}{c}-0.15 \\
(0.145)\end{array}$ & $\begin{array}{c}-0.19 \\
(0.145)\end{array}$ \\
\hline Constant & $\begin{array}{c}8.402 * * * \\
(2.913)\end{array}$ & $\begin{array}{l}-0.31^{* *} \\
(0.139)\end{array}$ & $\begin{array}{c}2.011 \\
(2.956)\end{array}$ & $\begin{array}{c}2.199 \\
(2.924)\end{array}$ & $\begin{array}{c}3.101 \\
(1.973)\end{array}$ & $\begin{array}{c}3.210 \\
(1.951)\end{array}$ & $\begin{array}{c}4.399 * * \\
(2.072)\end{array}$ & $\begin{array}{c}4.466 * * \\
(2.048)\end{array}$ \\
\hline $\mathrm{N}$ & 371 & $8.296 * * *$ & 371 & 371 & 371 & 371 & 371 & 371 \\
\hline R-squared & 0.328 & 2.872 & 0.402 & 0.409 & 0.363 & 0.319 & 0.371 & 0.327 \\
\hline
\end{tabular}

Notes: See text for explanation of variables and sources. All regressions are conducted with country fixed effects. Analysis excludes industrialized economies. Figures in parentheses are standard errors. *** denotes significance at $1 \%$-level, ${ }^{* *}$ denotes significance at 5\%-level, and * denotes significance at $10 \%$-level.

\section{IV.3 Combining Progressive Taxation and Consumption Taxes}


An additional constraint may be tax compliance, which countries may try to improve through the implementation of a consumption tax. We test if the combination of a VAT and progressive income taxation improves economic stability. To do so, we re-estimate the regression model for economic stability as before, but include the VAT as explanatory variable.

The results indicate that countries with a VAT and progressive taxation are actually less stable than the countries without a VAT (Table 10). In particular, a higher VAT reduces economic stability, at least in the short-run, possibly because it may have adverse effects on aggregate demand growth. This may indicate that the effectiveness of countercyclical fiscal policy could be reduced in the short-run due to the existence of a VAT. Second, capital inflows are again positively correlated with economic stability, both in the short-run and in the long-run. The size of the estimated coefficient, though, is larger than before. Given that large swings in portfolio flows often underlie economic volatility, this result suggests that countries with a VAT and progressive income taxation may be more exposed to the vagaries of international capital flows than countries without a VAT and just progressive personal income taxation.

Table 10 Regression Analysis of Determinants of Economic Stability with VAT

\begin{tabular}{|c|c|c|c|c|c|}
\hline Explanatory variable & $\begin{array}{l}\text { Baseline } \\
\text { (1) }\end{array}$ & $\begin{array}{l}\text { Top marginal tax } \\
\text { rate (Frazer) }\end{array}$ & $\begin{array}{l}\text { Top marginal } \\
\text { tax rate (AEI) }\end{array}$ & $\begin{array}{l}\text { Avg. tax } \\
\text { rate }\end{array}$ & $\begin{array}{l}\text { Median } \\
\text { tax rate }\end{array}$ \\
\hline \multirow{2}{*}{$\begin{array}{l}\text { Investment to GDP } \\
\text { (differenced) }\end{array}$} & $0.217^{* * *}$ & $0.210^{* * *}$ & $0.211^{* * *}$ & $0.214^{* * *}$ & $0.216^{* * *}$ \\
\hline & 0.022 & 0.023 & 0.022 & 0.022 & 0.022 \\
\hline \multirow{2}{*}{$\begin{array}{l}\text { Indicator for } \\
\text { countercyclicality } \\
\text { (differenced) }\end{array}$} & $0.033 * *$ & $0.033 * * *$ & $0.033 * * *$ & $0.032 * *$ & $0.032 * *$ \\
\hline & 0.012 & 0.012 & 0.012 & 0.012 & 0.012 \\
\hline \multirow{2}{*}{$\begin{array}{l}\text { Inc. share of bottom 20\% } \\
\text { (differenced) }\end{array}$} & -0.02 & -0.00 & -0.01 & -0.01 & -0.01 \\
\hline & 0.065 & 0.067 & 0.065 & 0.066 & 0.066 \\
\hline \multirow{2}{*}{$\begin{array}{l}\text { Capital inflows to GDP } \\
\text { (differenced) }\end{array}$} & $0.067^{*}$ & $0.064^{*}$ & $0.068 *$ & $0.067 *$ & $0.068 *$ \\
\hline & 0.037 & 0.037 & 0.036 & 0.036 & 0.037 \\
\hline \multirow[t]{2}{*}{ VAT (differenced) } & $-0.08^{* *}$ & $-0.07 * *$ & $-0.09 * * *$ & $-0.08 * *$ & $-0.08^{* *}$ \\
\hline & 0.034 & 0.034 & 0.035 & 0.034 & 0.034 \\
\hline \multirow{2}{*}{$\begin{array}{l}\text { Top marginal tax rate } \\
\text { (Frazer) (differenced) }\end{array}$} & & -0.04 & & & \\
\hline & & 0.035 & & & \\
\hline \multirow{2}{*}{$\begin{array}{l}\text { Top marginal tax rate } \\
\text { (AEI) (differenced) }\end{array}$} & & & $-0.02 *$ & & \\
\hline & & & 0.011 & & \\
\hline \multirow{2}{*}{$\begin{array}{l}\text { Average tax rate } \\
\text { (differenced) }\end{array}$} & & & & -0.01 & \\
\hline & & & & 0.011 & \\
\hline \multirow{2}{*}{$\begin{array}{l}\text { Median tax rate } \\
\text { (differenced) }\end{array}$} & & & & & -0.01 \\
\hline & & & & & 0.011 \\
\hline \multirow{2}{*}{$\begin{array}{l}\text { Investment to GDP } \\
\text { (lagged) }\end{array}$} & -0.01 & -0.01 & -0.02 & -0.01 & -0.01 \\
\hline & 0.019 & 0.019 & 0.019 & 0.019 & 0.019 \\
\hline \multirow{2}{*}{$\begin{array}{l}\text { Indicator for } \\
\text { countercyclicality (lagged) }\end{array}$} & $0.045^{* * *}$ & $0.046^{* * *}$ & $0.045^{* * *}$ & $0.044 * * *$ & $0.044^{* * *}$ \\
\hline & 0.017 & 0.017 & 0.016 & 0.017 & 0.017 \\
\hline \multirow{2}{*}{$\begin{array}{l}\text { Inc. share of bottom 20\% } \\
\text { (lagged) }\end{array}$} & -0.00 & 0.025 & 0.030 & 0.007 & 0.001 \\
\hline & 0.083 & 0.086 & 0.083 & 0.083 & 0.083 \\
\hline \multirow{2}{*}{$\begin{array}{l}\text { Capital inflows to GDP } \\
\text { (lagged) }\end{array}$} & $0.089 *$ & $0.087^{* *}$ & $0.093 *$ & $0.091 *$ & $0.091^{*}$ \\
\hline & 0.049 & 0.051 & 0.049 & 0.049 & 0.049 \\
\hline VAT (lagged) & -0.01 & -0.01 & -0.02 & -0.01 & -0.01 \\
\hline
\end{tabular}




\begin{tabular}{|c|c|c|c|c|c|}
\hline $\begin{array}{l}\text { Top marginal tax rate } \\
\text { (Frazer) (lagged) }\end{array}$ & 0.019 & $\begin{array}{c}0.020 \\
-0.01^{* *} \\
0.007\end{array}$ & 0.020 & 0.019 & 0.019 \\
\hline $\begin{array}{l}\text { Top marginal tax rate } \\
\text { (AEI) (lagged) }\end{array}$ & & & $\begin{array}{c}-0.01 * * \\
0.007\end{array}$ & & \\
\hline Average tax rate (lagged) & & & & $\begin{array}{c}-0.01 * \\
0.009\end{array}$ & \\
\hline Median tax rate (lagged) & & & & & $\begin{array}{c}-0.01^{*} \\
0.009\end{array}$ \\
\hline Constant & $\begin{array}{c}1.231^{*} \\
0.715\end{array}$ & $\begin{array}{c}1.512^{*} \\
0.797\end{array}$ & $\begin{array}{c}2.119 * * * \\
0.795\end{array}$ & $\begin{array}{c}1.804^{* *} \\
0.766\end{array}$ & $\begin{array}{c}1.767^{* *} \\
0.769\end{array}$ \\
\hline $\mathrm{N}$ & 217 & 217 & 217 & 217 & 217 \\
\hline R-Squared & 0.430 & 0.437 & 0.450 & 0.442 & 0.440 \\
\hline
\end{tabular}

Notes: See text for explanation of variables and sources. All regressions are conducted with country fixed effects. Analysis excludes industrialized economies. Figures in parentheses are standard errors. ${ }^{* * *}$ denotes significance at $1 \%$-level, ${ }^{* *}$ denotes significance at 5\%-level, and * denotes significance at $10 \%$-level.

\section{Conclusion}

In this paper, we consider the evidence on the relationship between progressive personal income taxation and economic stability. We study the short-term link of progressive taxation on economic stability through its effect on portfolio capital flows and the ability of governments to conduct countercyclical fiscal policy. In addition, we study the longer-term connection between progressive taxation and economic stability through its impact on income inequality and growth, whereby improvements in both may ultimately translate into less volatility.

We conclude that greater progressiveness allows countries to engage in countercyclical fiscal policy and thus creates the policy space to stabilize economic fluctuations, both in the short-run and long-run.

There is, however, a potential tradeoff as more progressive taxation is also associated with less stability in the long-run due to factors not directly accounted for in our empirical model, such as human capital development. In the end, though, the potential stability enhancing benefits from more countercyclical fiscal policy far outweigh such countervailing effects.

The implementation of progressive taxation, though, seems particularly constrained in open economies. In particular, greater capital mobility and increased corporate tax competition tend to go along with less progressive personal income taxation, especially due to reductions in top marginal tax rates. There may be a common non-economic explanation that links greater economic integration to lower personal and corporate income tax rates. Investigating such a potential non-economic link will have to be investigated in future research.

Another potential constraint on the implementation of progressive personal income taxation may the presence of ineffective tax collection, which may lead countries to increasingly rely on consumption taxes, such as the value added tax. Our results, though, indicate that the combination of a value added tax with progressive personal income taxation may reduce the 
stability benefits of progressive taxation. In particular, the presence of a VAT is also associated with a greater exposure to short-term portfolio capital flows, which are often associated with increased economic volatility.

These results may tentatively suggest a few policy conclusions. In particular, industrializing economies can raise economic stability through progressive income taxation. This is easier to accomplish with less capital account liberalization. Moreover, the benefits may be offset when countries introduce consumption taxes at the same time. 


\section{References}

Alba, P., L. Hernandez and D. Klingebiel. 1999. Financial Liberalization and the Capital Account: Thailand 1988-1997. Policy Research Working Paper No. 2188, September, World Bank, Washington, DC.

American Enterprise Institute, 2006, International Tax Database, Washington, D.C.: AEI.

Arestis, P. and P. Demetriades. 1999. 'Financial liberalization: The experience of developing countries.’ Eastern Economic Journal, Vol. 25, No. 4 (Fall), pp. 441-457.

Auerbach, A., and Feenberg, D., 2000, The Significance of Federal Taxes as Automatic Stabilizers, Journal of Economic Perspectives 14, No.3:37-56.

Balassa, B., 1989, Tariff Policy and Taxation in Developing Countries, WB Policy Research Working Paper No. 281, Washington, D.C.: The World Bank.

Barsky, R., Makiw, G., and Zeldes, S., 1986, Ricardian Consumers with Keynesian Propensities, American Economic Review 76, No.4: 676-691.

Bird, R., and Zolt, E., 2005, Redistribution via Taxation: The Limited Role of the Personal Income Tax in Developing Countries, AYSPS International Studies Program Working Paper, Atlanta, GA: Georgia State University, Andrew Young School of Policy Studies.

Blecker, R. 1999. Taming Global Finance: A Better Architecture for Growth and Equity. Economic Policy Institute, Washington, DC.

Bovenberg, A. and van Ewijk, C., 1997, Progressive Taxes, Equity, and Human Capital Accumulation in an Endogenous Growth Model with Overlapping Generations, Journal of Public Economics 64, No.2: 153-179.

Caucutt, E., Imrohoroglu, S., and Kumar, K., 2006, Does the Progressiveness of Income Taxes Matter for Human Capital and Growth?, Journal of Public Economic Theory 8, No.1:95-118.

Decoster, A., 2005, How Progressive are Indirect Taxes in Russia?, Economics of Transition 2005:705-29.

Deininger, K. and L. Squire, 1996, ‘A New Data Set Measuring Income Inequality’, The World Bank Economic Review, Vol. 10, No3.

Demetriades, P. and B.A. Fattouh. 1999. 'South Korea’s financial liberalization: An experiment in faith.’ International Affairs, Vol. 75, No. 4, pp.779-792.

Dollar, D. and A. Kraay, 2001, 'Growth is Good for the Poor', World Bank Development Research Group Working Paper No. 2587, http://econ.worldbank.org/files/1696_wps2587.pdf. 
Economic Council on Latin America and the Caribbean (ECLAC), 1997, 'The Equity Gap: Latin America, the Caribbean, and the Social Summit’, LG/G, 1954.(CONF86/3), Santiago, Chile, March 1997.

Engel, E., Galetovic, A., Raddatz, C., 1998, Taxes and Income Distribution in Chile: Some Unpleasant Redistributive Arithmetic, NBER Working Paper No. 6828, Cambridge, MA: National Bureau of Economic Research.

Faux, J. and L. Mishel, 2000, 'Inequality and the Global Economy', in Hutton, W. and A. Giddens (eds.), On the Edge: Living with Global Capitalism, London, UK: Jonathan Cape.

Fraser Institute, 2005, Economic Freedom Database, Vancouver, BC, Canada: Fraser Institute.

Galmarini, U., 1997, On the Size of the Regressive Bias in Tax Enforcement, Economic Notes 26, No.1: 75-102.

Grabel, I. 1998. 'Rejecting exceptionalism: Reinterpreting the Asian financial crises.' In J. Michie and J. Grieve Smith (eds.), Global Instability and World Economic Governance. Routledge, Oxford.

Hassan, F., and Bogetic, Z., 1999, Distribution of Income and the Income Tax Burden in Bulgaria, WB Policy Research Working Paper No. 1421, Washington, D.C.: The World Bank.

Hassett, K., and Mathur, A., 2006, Taxes and Wages, paper presented at the American Enterprise Institute conference "Corporate Income Taxation and the Economy”, Washington, D.C., August.

Inter-American Development Bank (IADB), 1999, 'Facing Up to Inequality in Latin America, Economic and Social Progress’ in Latin America, 1998-1999 Report, Washington, D.C.: IADB.

Jenkins, G., Jenkins, H., and Kuo, C., 2006, Is the Value Added Tax Naturally Progressive?, Queens University, Department of Economics, Working Paper No. 1059, Kingston, Ontario, Canada: Queen’s University.

Leibfritz, W., Thornton, J., and Bibbee, A., 1997, Taxation and Economic Performance, OECD Working Paper No. 176, Paris, France: Organization for Economic Cooperation and Development.

Levine, R. 1997. 'Financial development and economic growth: Views and agenda.' Journal of Economic Literature, Vol. 35, No. 2, pp. 688-727.

Levine, R. 2001. 'International financial liberalization and economic growth.' Review of International Economics, Vol. 9, No. 4, pp. 688-702.

Li, W., and Sartre, P., 2004, Progressive Taxation and Long-Run Growth, American Economic Review 94, No.5:1705-1716. 
Li, W., and Sartre, P. 2001, Growth Effects of Progressive Taxes, Federal Reserve Bank of Richmond Working Paper 01-9, Richmond, VA: Federal Reserve Bank of Richmond.

Litan, R., P. Masson, and M. Pomerleano. 2001. Open Doors: Foreign Participation in Financial Systems in Developing Countries. Brookings Institution Press, Washington, DC.

Lustig, N. 2000. Crises and the Poor: Socially Responsible Macroeconomics. Sustainable Development Department Technical Paper Series No. POV-108, Inter-American Development Bank, Washington, DC.

Lustig, N. and R. Deutsch, 1998, 'The Inter-American Development Bank and Poverty Reduction: An Overview', No. POV-101-R, Washington, D.C.: IADB.

Munoz, S., and Sang-Wook Cho, 2003, Social Impact of Tax Reform: The Case of Ethiopia, IMF Working Paper No. 03/232, Washington, D.C.: International Monetary Fund.

Nishiyama, S., and Smetters, K., 2005, Consumption Taxes and Economic Efficiency with Idiosyncratic Wage Shocks, Journal of Political Economy 113, No.5:1088-1115.

Picketty, T., and Quian, N., 2006, Income Inequality and Progressive Income Taxation in China and India, CEPR Discussion Paper No. 5703, London, UK: Centre for Economic and Policy Research.

Ramey, G., and Ramey, V., 1995, Cross-Country Evidence on the Link Between Volatility and Growth, American Economic Review 85, No.4: 1138-1151.

Ravallion, M. and S. Chen, 1997, 'What Can New Survey Data Tell Us About Recent Changes in Distribution and Poverty?', The World Bank Economic Review, Vol. 11, No. 2.

Roed, K., and Strom, S., 2002, Progressive Taxes and Labour Market: Is the Trade-off Between Equality and Efficiency Inevitable?, Journal of Economic Surveys 16, No.1: 77-110.

Schmitt, J. 2003. Is it Time to Export the U.S. Tax Model to Latin America? Briefing Paper, Center for Economic and Policy Research, Washington, DC.

Scotchmer, S., The Regressive Bias in Tax Enforcement, Public Finance 47 (Supplement 1992): 366-71.

Stock, J., and Watson, M. W., 1993, A Simple Estimator of Cointegrating Vectors in Higher Order Integrated Systems, Econometrica 61, No. 4: 783-820

Tanzi, V. and H. Zee. 2000. Tax Policy for Emerging Markets: Developing Countries. Working Paper WP/00/35, International Monetary Fund, Washington, DC. 
Thierfelder, K., Robinson, S., Kearney, M., and Delfin, S., 2005, An Analysis of South Africa's Value Added Tax, WB Policy Research Working Paper No. 3671, Washington, D.C.: The World Bank.

United Nations Conference on Trade and Development (UNCTAD), 1997, Trade and Development Report, Geneva, Switzerland: UNCTAD.

Weller, C. 2001. 'Financial crises after financial liberalization: Exceptional circumstances or structural weakness?’ The Journal of Development Studies, Vol. 38, No. 1, pp. 98-127.

Weller, C. and L. Singleton. 2004. 'Political freedom, external liberalization, and financial stability.' International Review of Applied Economics, Vol. 18, No. 1, pp. 43-61.

World Bank, 2001b, Global Poverty Monitoring Database, www.worldbank.org/research/pomonitor/

Younger, S., Sahn, D., Haggblade, S., and Dorosh, P., 1999, Tax Incidence in Madagascar: An Analysis Using Household Data, World Bank Economic Review 13, No.2: 303-31. 